\title{
Estradiol increases risk of topoisomerase II $\beta$-mediated DNA strand breaks to initiate Xp11.2 translocation renal cell carcinoma
}

\author{
Qiancheng Shi', Ning Liu², Lei Yang ${ }^{3,4}$, Yi Chen ${ }^{3,4}$, Yanwen Lu' ${ }^{1}$, Hongqian Guo ${ }^{1}$, Xiaodong Han³, \\ Dongmei $\mathrm{Li}^{3,4^{*}}$ and Weidong Gan ${ }^{1^{*}}$ (D)
}

\begin{abstract}
Background: Xp11.2 translocation renal cell carcinoma (tRCC) is defined by translocation of the transcription factor E3 (TFE3) gene located on chromosome Xp1 1.2. Due to the high incidence in women, 17ß-estradiol (E2) may be a factor influencing TFE3 breaks, and the topoisomerase II (TOP2) poison is considered one of the important risk factors in mediating DNA breaks. In this study, we investigated the potential pathogenesis of Xp11.2 tRCC using the renal epithelial cell line HK-2.
\end{abstract}

Methods: Immunofluorescence assay was performed to analyze DNA breaks by quantifying phosphorylation of $\mathrm{H} 2 \mathrm{AX}(\mathrm{\gamma H} 2 \mathrm{AX})$, and the micronuclei $(\mathrm{MN})$ assay was designed for monitoring chromosome breaks. The chromatin immunoprecipitation (CHIP) was used to detect whether proteins bound to specific DNA site, and the co-immunoprecipitation (Co-IP) was used to confirm whether proteins bound to other proteins. In some experiments, siRNA and shRNA were transfected to knockdown target genes.

Results: Our results demonstrated that DNA double-strand breaks were mediated by TOP $2 \beta$ in HK-2 cells, and this process could be amplified through estrogen receptor a (ERa)-dependent pathway induced by E2. After performing translocation site analysis using target region sequencing data in two Xp11.2 tRCC cell lines and ten Xp11.2 tRCC patients, we confirmed that TOP $2 \beta$ and ERa could both bind to TFE3 translocation sites directly to mediate DNA breaks in a E2-dependent manner. However, TOP2 $\beta$ and ERa were not observed to have direct interaction, indicating that their collaborative may be implemented in other ways. Besides, TFE3 was found to be upregulated through NRF1 with increasing E2 concentration, which could increase the risk of TFE3 breaks.

Conclusion: Our results indicate that E2 amplifies TOP2 $\beta$-mediated TFE3 breaks by ERa-dependent pathway, and E2 upregulates TFE3 by NRF1 to increase the risk of TFE3 breaks. This suggests that E2 is an important pathogenic factor for Xp11.2 tRCC pathogenesis.

Keywords: Renal cell carcinoma, Xp11.2, Estradiol, Estrogen receptor, Topoisomerase, TFE3

*Correspondence: lidm@nju.edu.cn; gwd@nju.edu.cn

${ }^{1}$ Department of Urology, Affiliated Drum Tower Hospital, Medical School

of Nanjing University, Nanjing, Jiangsu, China

${ }^{3}$ Immunology and Reproduction Biology Laboratory and State Key

Laboratory of Analytical Chemistry for Life Science, Medical School, Nanjing University, Nanjing, Jiangsu, China

Full list of author information is available at the end of the article

\section{Background}

Xp11.2 translocation renal cell carcinoma (tRCC), first reported in 1988, is characterized by a pathognomonic chromosomal translocation of transcription factor E3 (TFE3), which causes fusion of the TFE3 gene with a variety of partner genes $[1,2]$. Children and young adults are most often affected, for $46.7 \%$ of paediatric RCCs and original author(s) and the source, provide a link to the Creative Commons licence, and indicate if changes were made. The images or other third party material in this article are included in the article's Creative Commons licence, unless indicated otherwise in a credit line to the material. If material is not included in the article's Creative Commons licence and your intended use is not permitted by statutory regulation or exceeds the permitted use, you will need to obtain permission directly from the copyright holder. To view a copy of this licence, visit http://creativecommons.org/licenses/by/4.0/. The Creative Commons Public Domain Dedication waiver (http://creativeco mmons.org/publicdomain/zero/1.0/) applies to the data made available in this article, unless otherwise stated in a credit line to the data. 
$15 \%$ of young adult (aged $<45$ years) RCCs are Xp11.2 tRCC, and the peak age of onset is 20-29 years [3-5]. Due to its aggressiveness, Xp11.2 tRCC is characterized by poor prognosis with local invasive and distant metastases [6-9], and the high prevalence of young adults increased the medical care related to complications of this disease in recent years. Another important feature of Xp11.2 tRCC is the female predominance. The female/ male ratio of Xp11.2 tRCC is $1.68-2[10,11]$, which is totally different from common RCCs [12]. Considering age- and sex-specific factors of this type of RCC, we suspect that estrogen may play an important role in the pathogenesis of Xp11.2 tRCC.

The topoisomerase II (TOP2) poison has been reported to be a causal agent of this type of RCC, for patients could have a history of TOP2 poisons (etoposide or doxorubicin) use before diagnosed with Xp11.2 tRCC [1315]. These drugs are used in the treatment of a variety of cancers as a broad class of chemotherapeutic agents [16]. The role of TOP2-mediated DNA double-strand breaks in translocation tumors especially MLL leukemia has been widely reported $[17,18]$. However, whether the
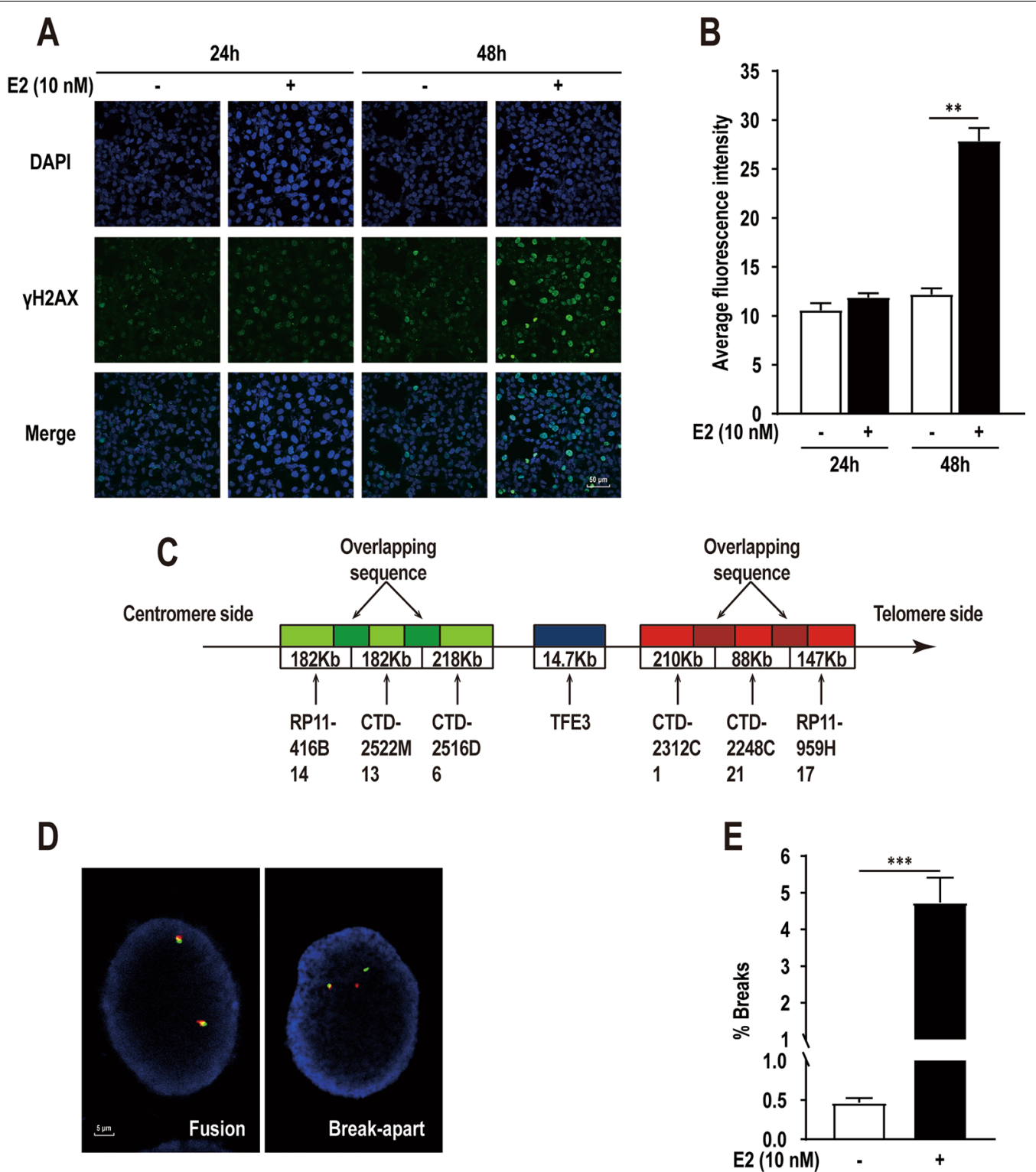

Fig. 1. 17ß-estradiol (E2)-induced DNA breaks and TFE3 breaks analysis. A Phosphorylation of H2AX ( $\mathrm{H} 2 \mathrm{AX})$ focis detected in HK-2 cells under $0.1 \%$ DMSO (solvent-only control) or $10 \mathrm{nM} \mathrm{E2} \mathrm{treatment} \mathrm{for} 24 \mathrm{~h}$ or $48 \mathrm{~h}$. B Quantification of the $\mathrm{YH} 2 \mathrm{AX}$ focis in E2-treated cells as in panel A. C Pattern diagram of TFE3 break-apart rearrangement probe. D Examples of fusion and break-apart signal using TFE3 break-apart breaksfluorescence in situ hybridization (FISH) probe. E Quantification of the TFE3 break-apart signals in HK-2 cells under 0.1\% DMSO (solvent-only control) or 10 nM E2 treatment for $48 \mathrm{~h}$. Error bars indicate $95 \%$ confidence intervals $\left({ }^{* *} p<0.01 ;{ }^{* * *} p<0.001\right.$ ) 

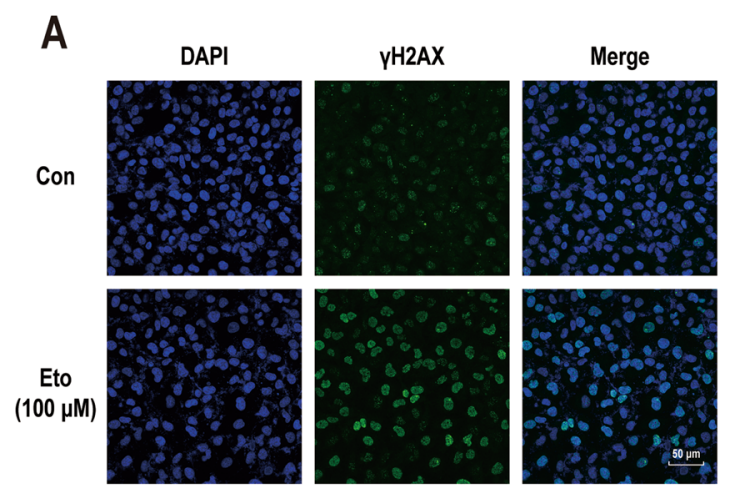

B

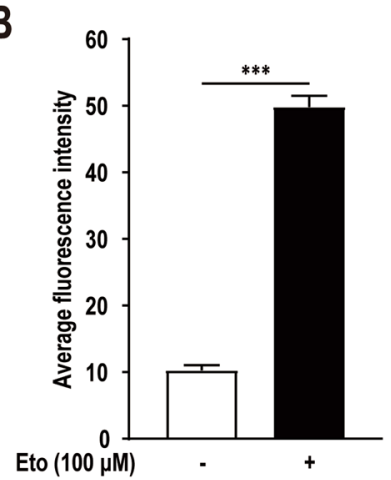

C

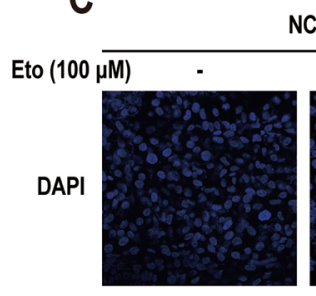

NC

SITOP2A
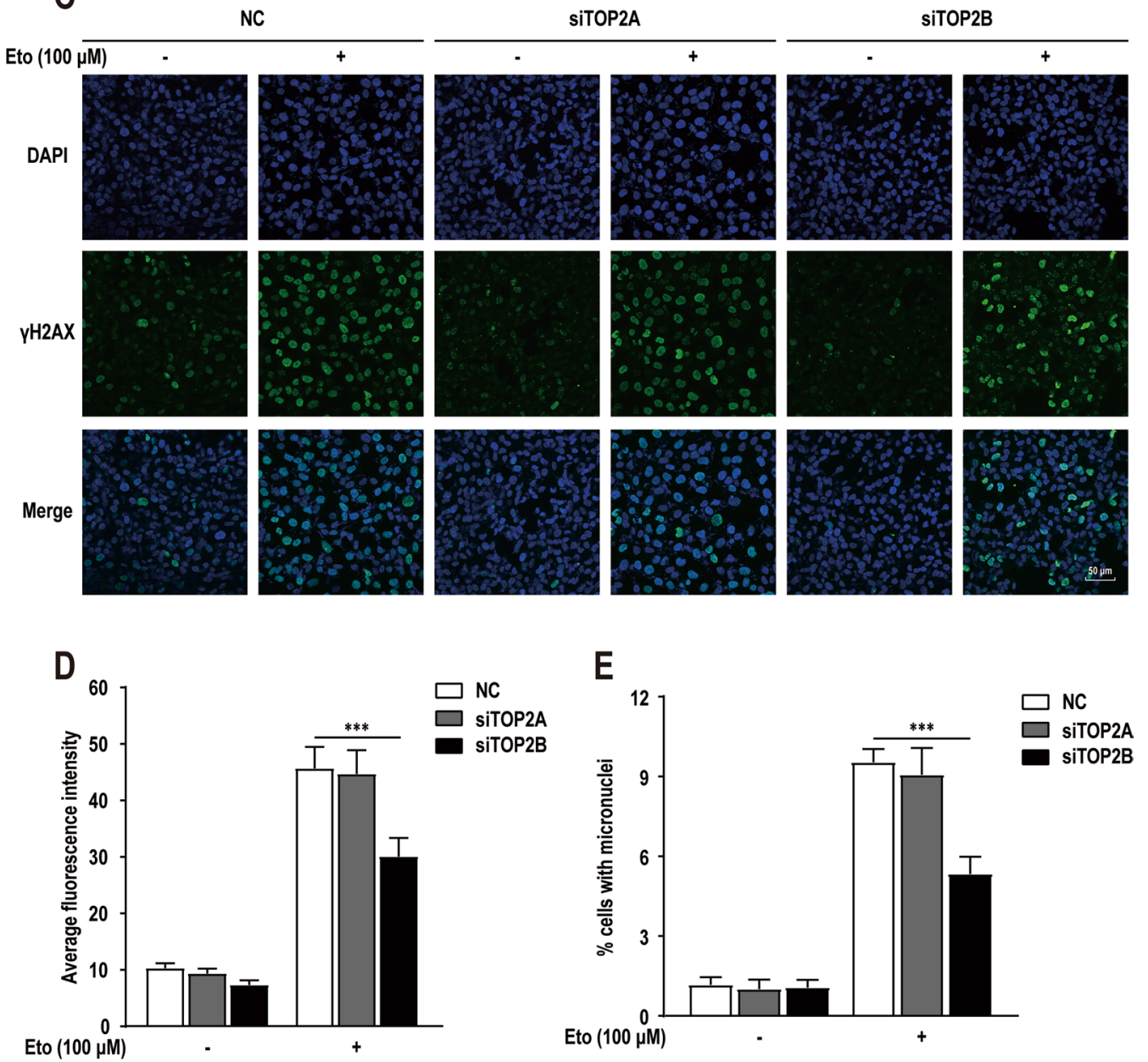

Fig. 2 Etoposide-induced topoisomerase II (TOP2)-mediated DNA breaks and chromosomal breaks. A $y$ H2AX focis detected in HK-2 cells under $0.1 \%$ DMSO (solvent-only control) or $100 \mu \mathrm{M}$ etoposide treatment for $1 \mathrm{~h}$. B Quantification of the $\mathrm{YH} 2 \mathrm{AX}$ focis in etoposide-treated cells as in panel A. C $\gamma \mathrm{H} 2 \mathrm{AX}$ focis detected in HK-2 cells transfected with negative control siRNA (NC), siRNA against TOP2A (siTOP2A), or siRNA against TOP2B (siTOP2B) under 0.1\% DMSO (solvent-only control) or $100 \mu \mathrm{M}$ etoposide treatment for $1 \mathrm{~h}$. D Quantification of the $\mathrm{\gamma H} 2 \mathrm{AX}$ focis in etoposide-treated cells as in panel C. E Quantification of the micronucleis (MNs) in etoposide-treated cells as in panel C. Error bars indicate $95 \%$ confidence intervals $\left({ }^{* *} p<0.001\right)$ 
specific TFE3 gene breaks in Xp11.2 tRCC are produced via TOP2-mediated DNA double-strand breaks is still unclear. Exploring the TOP2-mediated DNA doublestrand breaks at TFE3 translocation sites has important implications in understanding the pathogenesis of Xp11.2 tRCC.

Since $17 \beta$-estradiol (E2) and estrogen receptor (ER)mediated DNA breaks have been reported [19, 20], we consider that E2 and ER may induce TFE3 breaks through TOP2-mediated DNA double-strand breaks in Xp11.2 tRCC. Thus, this study was designed to confirm the role of TOP2-mediated DNA double-strand breaks in TFE3 translocation sites of Xp11.2 tRCC, and the regulatory functions of E2 and ER in this process.

\section{Materials and methods Cell culture}

HK-2 cells were obtained from ATCC $\left(\right.$ ATCC $^{\circledR}$ CRL$\left.2190^{\mathrm{TM}}\right)$, and then authenticated by STR profiling at Shanghai Zhong Qiao Xin Zhou Biotechnology Co., Ltd. These HK-2 cells were cultured in base medium provided by Invitrogen (GIBCO) supplemented with $0.05 \mathrm{mg} /$ $\mathrm{ml}$ bovine pituitary extract (BPE) and $5 \mathrm{ng} / \mathrm{ml}$ human recombinant epidermal growth factor (EGF) in $5 \% \mathrm{CO}_{2}$ at $37{ }^{\circ} \mathrm{C}$. For etoposide stimulation, HK-2 cells were plated in base medium with $0.05 \mathrm{mg} / \mathrm{ml} \mathrm{BPE}$ and $5 \mathrm{ng} / \mathrm{ml} \mathrm{EGF}$ for a minimum of $16 \mathrm{~h}$ before being washed 3 times in $1 \times$ PBS. The same medium was then added for $1 \mathrm{~h}$ prior to the addition of etoposide dissolved in DMSO or the vehicle control (100\% DMSO). For estrogen stimulation, HK-2 cells were pre-processed using the same approach as mentioned earlier, and the same medium with E2 dissolved in DMSO or the vehicle control were then added for $24 \mathrm{~h}$ or $48 \mathrm{~h}$. UOK109 and UOK120 cells were gifts of Dr. W. Marston Linehan, National Cancer Institute, Bethesda, MD. The UOK109 and UOK120 cell lines were derived from primary RCC as described [21], and were derived from tumors arising in a 30 - and a 39 -year-old male, respectively. These UOK109 and UOK120 cells were cultured in DMEM (GIBCO) supplemented with $10 \% \mathrm{FBS}$ in $5 \% \mathrm{CO}_{2}$ at $37^{\circ} \mathrm{C}$.
Antibodies, plasmids, reagents, and primers

Antibodies to P-H2AX (Cell Signaling, 80312S), TOP2 $\beta$ (Abcam, ab72334), CTCF (Abcam, ab128873), ER- $\alpha$ (Cell Signaling, 8644S), and Alexa Fluor Plus 488 (Invitrogen, A32723) were used. Two siRNA were used to deplete $T O P 2 A$ and TOP $2 B$ separately, and NC siRNA was used for negative control. Three shRNA were used to knockdown ESR1, ESR2 and NRF1 separately, and NC shRNA was used for negative control. The siRNA sequences and shRNA sequences can be found in the supplementary materials [see Additional file 1]. All siRNA transfections were performed using Lipofectamine $2000^{\mathrm{TM}}$ (Thermo Fisher, 11668019) according to the manufacturer's protocol and $20 \mathrm{nM}$ siRNA. All lentiviral vectors expressing the scramble shRNA transfections were performed using polybrene (Sigma-Aldrich, TR-1003). Etoposide (SigmaAldrich, E1383) and E2 (Sigma-Aldrich, E8875) was dissolved in DMSO (Sigma-Aldrich, D2650). All primers and primer sequences can be found in the supplementary materials [see Additional file 1].

\section{Relative quantitative real-time polymerase chain reaction}

The action mixture consisted of $10 \mu \mathrm{l}$ SYBR Green (Vazyme, Nanjing, Q711-02), $10 \mu \mathrm{M}$ each primer, $1 \mu \mathrm{l}$ cDNA. PCR amplifications were performed on the 7300 real-time PCR system (Applied Biosystems, CA, US). The relative mRNA expression level was calculated by the comparative $2^{-\Delta \Delta \mathrm{Ct}}$ method and normalized against ACTB mRNA. For reverse transcription-PCR analysis, amplification was done for 33 cycles, each with denaturation at $95{ }^{\circ} \mathrm{C}$ for $30 \mathrm{~s}$, annealing at $60^{\circ} \mathrm{C}$ for $30 \mathrm{~s}$ and extension at $72{ }^{\circ} \mathrm{C}$ for $30 \mathrm{~s}$.

\section{Micronuclei assays}

Cytochalasin B (MCE, HY-16928) and Acridine Orange (Sigma-Aldrich, A6014) were used for micronuclei assays as reported in literature [22].

\section{Fluorescence in-situ hybridization (FISH)}

FISH was performed using FISH Tag DNA Green Kit (Thermo Fisher, F32947).

\footnotetext{
(See figure on next page.)

Fig. 3 Etoposide-induced TOP2-mediated TFE3 breaks in Xp11.2 translocation renal cell carcinoma (tRCC) translocation sites. A Quantification of the TFE3 break-apart signals in HK-2 cells under $0.1 \%$ DMSO (solvent-only control) or $100 \mu \mathrm{M}$ etoposide treatment for $1 \mathrm{~h}$. B Quantification of the TFE3 break-apart signals in HK-2 cells transfected with NC or siTOP2B under $0.1 \%$ DMSO (solvent-only control) or $100 \mu \mathrm{M}$ etoposide treatment for $1 \mathrm{~h}$. $\mathbf{C}$ Ideograms of the translocation fragments of two Xp11.2 tRCC cell lines, UOK109 and UOK120. D and E Statistics of TOP2 $\beta$ chromatin immunoprecipitation (ChIP)-qPCR results performed using the primers near the translocation sites as in panel $\mathbf{c}$ in HK-2 cells under $0.1 \%$ DMSO (solvent-only control) or $100 \mu \mathrm{M}$ etoposide treatment for $1 \mathrm{~h}$. $\mathbf{F}$ and $\mathbf{G}$ Statistics of CTCF ChIP-qPCR results performed using the same primers as in panel $\mathbf{D}$ and $\mathbf{E}$ in HK-2 cells. ChIP-qPCR was normalized to Input DNA, experiments were repeated three times and data shown are means \pm SD. Error bars indicate $95 \%$ confidence intervals $\left({ }^{*} p<0.05 ;{ }^{* *} p<0.01 ;{ }^{* *} p<0.001\right)$
} 
A

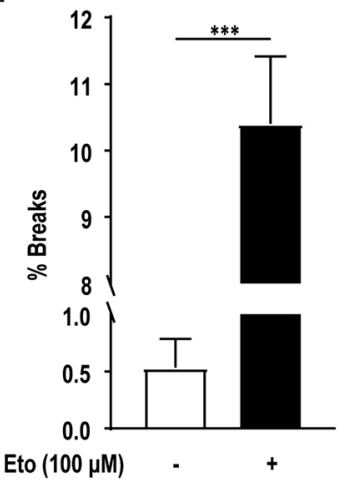

C

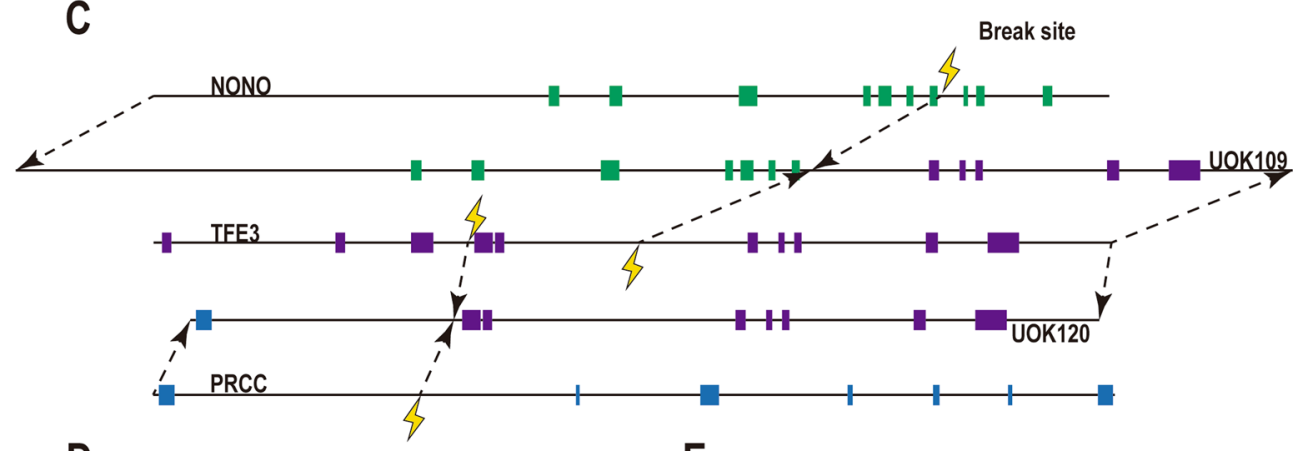

D

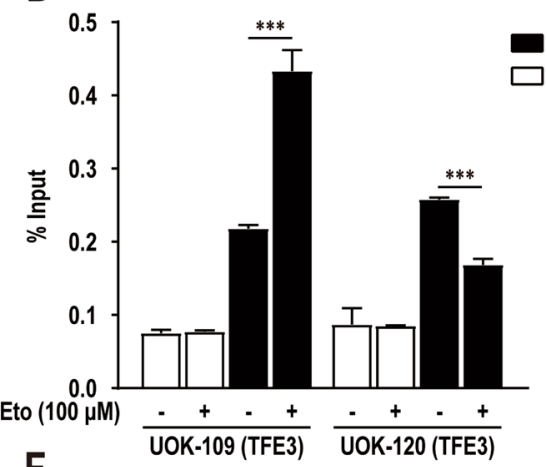

$\mathrm{F}$

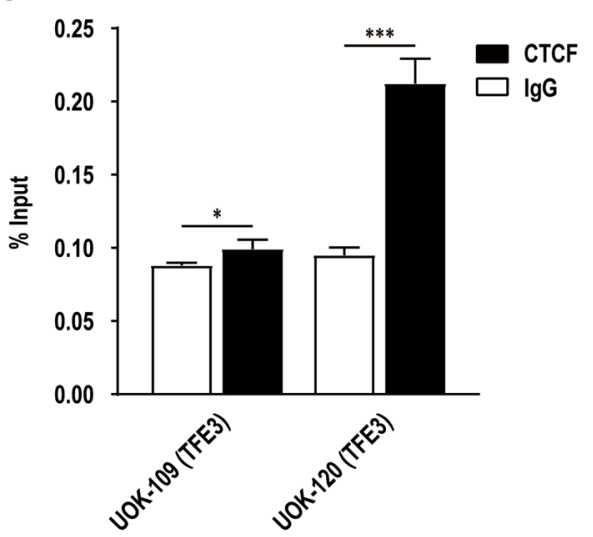

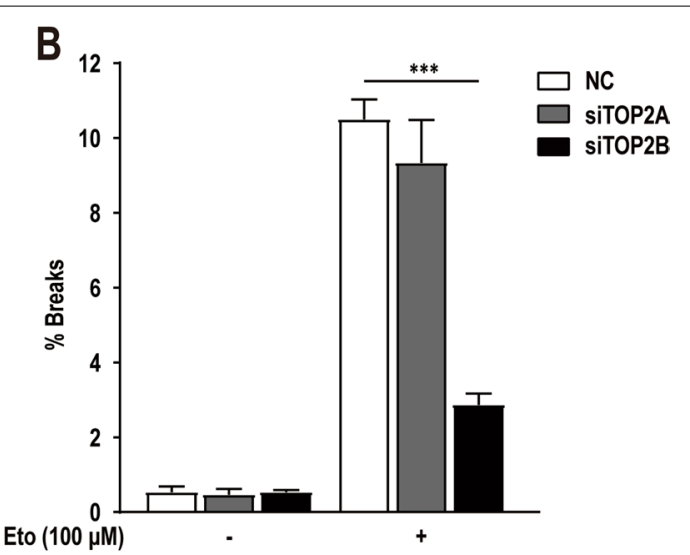

E

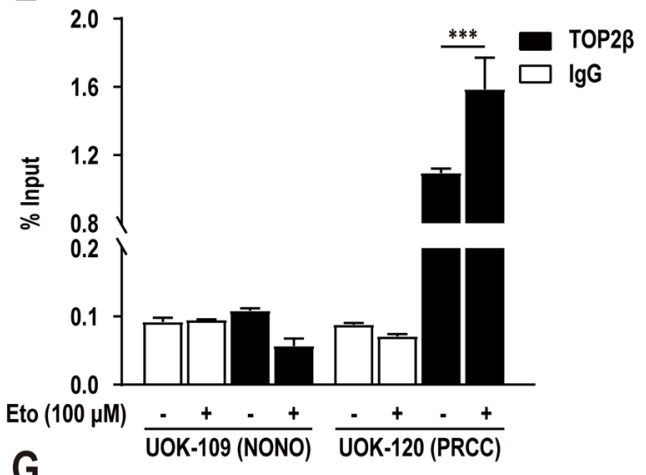

G

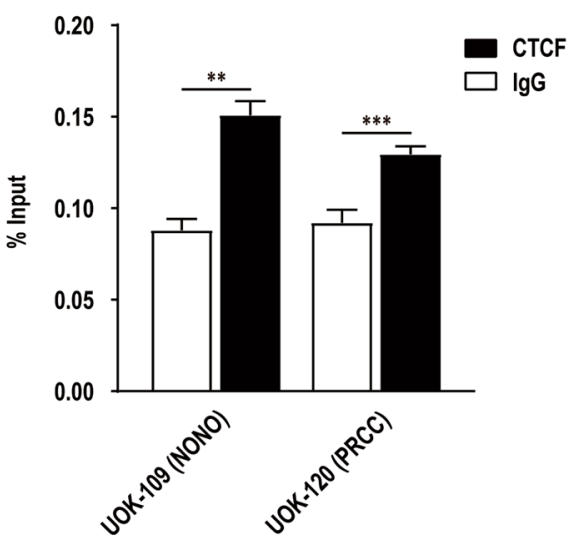

Fig. 3 (See legend on previous page.) 
BAC clones CTD-2516D6 (TFE3-5'), CTD-2522M13 (TFE3-5' $), \quad$ RP11-416814 (TFE3-5'), CTD-2312C1 (TFE3-3'), CTD-2248C21 (TFE3-3'), RP11-959H17 (TFE3-3') were selected from The UCSC Genome Browser (http://genome.ucsc.edu). Probes were labeled with FITC (all 5' probes) and TexasRed (all $3^{\prime}$ probes) conjugated dUTP (C7604, C7631, Invitrogen). The fusion signal appears as one yellow signal superimposed by one red and one green signal together, and the separated signal appears as the distance between the red and the green signals more than one signal point diameter. Since the female cell line we used contain two $\mathrm{X}$ chromosomes, the negative result presents two yellow fusion signals, and the positive result presents one yellow fusion signal and two separate signals (one red and one green).

\section{Chromatin immunoprecipitation (ChIP)}

Chromatin immunoprecipitation was performed using Pierce Magnetic ChIP Kit (Thermo Fisher, 26157). The HK-2 cells were crosslinked using formaldehyde with a final concentration of $1 \%$, and the number of cells required $2 \times 10^{6}$.

\section{Co-immunoprecipitation (Co-IP)}

Co-IP was performed using Pierce Co-Immunoprecipitation Kit (Thermo Fisher, 26149). For each IP, $8 \mu \mathrm{g}$ antibody (ER- $\alpha$ (Cell Signaling, 8644S)) was added.

\section{Results}

\section{E2 induces TFE3 breaks in HK-2 cells}

Considering the potential oncogenic role of E2 in the pathogenesis of Xp11.2 tRCC, we assessed the ability of E2 to induce DNA breaks. The renal epithelial cell line HK-2 was treated with E2 at a concentration of $10 \mathrm{nM}$, and the histone H2AX phosphorylation was used as an indicator for reflecting DNA double-strand breaks. When using immunofluorescent staining to detect phosphorylated H2AX ( $\gamma$-H2AX) foci, E2 induced remarkably breaks more than control group after $48 \mathrm{~h}$ (Fig. 1A, B). To directly assess the role of E2 in generating breaks at the TFE3 locus, we used DNA-FISH with a "break-apart" rearrangement probe to quantify TFE3 breaks (Fig. 1C, D). E2 could induce TFE3 breaks significantly after $48 \mathrm{~h}$ at the concentration of $10 \mathrm{nM}$ in HK-2 cells (Fig. 1E). The results confirm the role of E2 in TFE3 breaks.

\section{TOP2 $\beta$ mediates DNA double-strand breaks}

To ascertain the role of TOP2-mediated DNA cleavage in renal carcinogenesis with chromosomal translocation, HK-2 cells were treated with the TOP2 poison etoposide at a concentration of $100 \mu \mathrm{M}$ for a short time period (1 h) (Additional file 4: Fig. S1A). Results showed that etoposide induced remarkably breaks more than control group (Fig. 2A, B). To determine which of the two TOP2 affected the etoposide-induced DNA damage across the genome, HK-2 cells were transfected with negative control siRNA (NC), siRNA against TOP $2 A$ (siTOP2A), or siRNA against TOP2B (siTOP2B) (Additional file 4: Fig. S1C). The immunofluorescence analysis showed similar results, DNA breaks of each group were extensively increased after etoposide treatment, but only $T O P 2 B$ knockdown significantly decreased the $\gamma-\mathrm{H} 2 \mathrm{AX}$ foci (Fig. 2C, D), indicating that TOP2B knockdown decreased DNA breaks. To verify the contribution made by TOP2 to etoposide-induced genotoxicity at the chromatin level, we next carried out micronuclei $(\mathrm{MN})$ assays (Additional file 4: Fig. S1D). The TOP2A knockdown group behaved in the same way as control group, whereas in $T O P 2 B$ knockdown group there was a significant decrease in the $\mathrm{MN}$ frequency of etoposide-treated cells (Fig. 2E). These results show that TOP2 $\beta$ mediates DNA double-strand breaks in HK-2 cells, supporting the role for TOP2 $\beta$ in the genotoxic effects of etoposide.

\section{TOP $2 \beta$ mediates TFE3 breaks directly}

To further clarify the specific mechanism of TFE3 breaks in Xp11.2 tRCC, we used DNA-FISH with a "break-apart" rearrangement probe as above described. Results showed that etoposide induced approximately 20 -fold breaks at the TFE3 locus in HK-2 cells, and breaks in the same position was substantially reduced in $T O P 2 B$ knockdown group (Fig. 3A, B). Subsequently, DNA sequences of the translocation site were analyzed via target region sequencing in two Xp11.2 tRCC cell lines, UOK109 and UOK120 (Fig. 3C and Additional file 1). We used ChIPqPCR to determine the distribution of TOP $2 \beta$ over the translocation sites in UOK109 and UOK120 cells, respectively. The results of sampling multiple translocation

\footnotetext{
(See figure on next page.)

Fig. 4 E2 induced-TFE3 breaks through ERa-dependent pathway. A $Y H 2 A X$ focis detected in HK-2 cells transfected with negative control shRNA (NC), shRNA against ESR1 (shESR1), or shRNA against ESR2 (shESR2) under 0.1\% DMSO (solvent-only control) or $10 \mathrm{nM} \mathrm{E2} \mathrm{treatment} \mathrm{for} 48 \mathrm{~h}$. B Quantification of the $\mathrm{YH} 2 \mathrm{AX}$ focis in E2-treated cells as in panel A. C Quantification of the MNs in E2-treated cells as in panel A. D Quantification of the TFE3 break-apart signals in HK-2 cells transfected with NC or shESR1 under $0.1 \%$ DMSO (solvent-only control) or $10 \mathrm{nM} \mathrm{E2} \mathrm{treatment} \mathrm{for} 48 \mathrm{~h}$. E and $\mathbf{F}$ Statistics of TOP2 $\beta$ ChIP-qPCR results performed using the primers near the translocation sites in HK-2 cells under $0.1 \%$ DMSO (solvent-only control) or $10 \mathrm{nM}$ E2 treatment for $48 \mathrm{~h}$. ChIP-qPCR was normalized to Input DNA, experiments were repeated three times and data shown are means \pm SD. Error bars indicate $95 \%$ confidence intervals $\left({ }^{* *} p<0.01 ;{ }^{* * *} p<0.001\right)$
} 


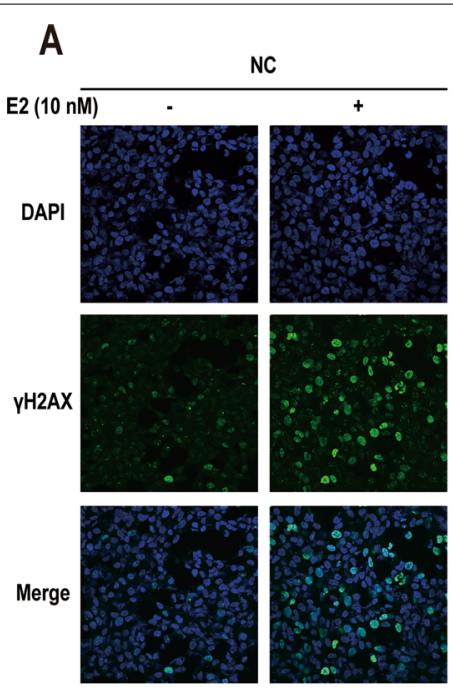

B

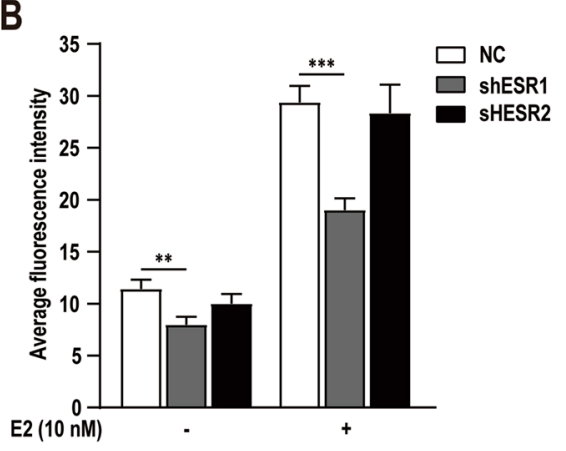

D
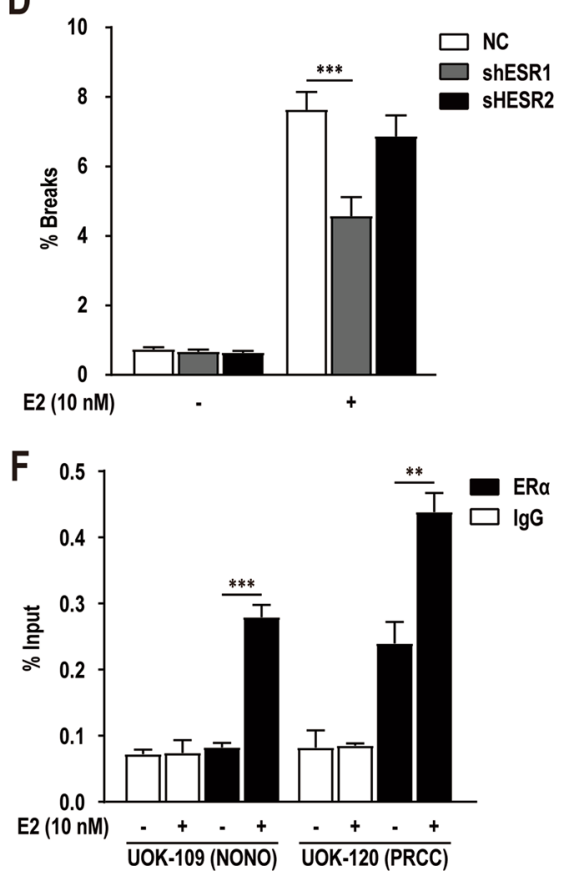

shESR1
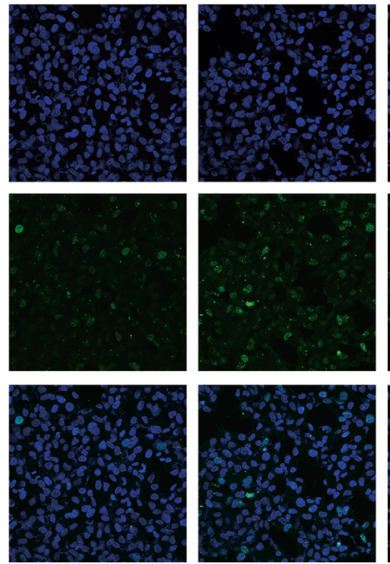

C

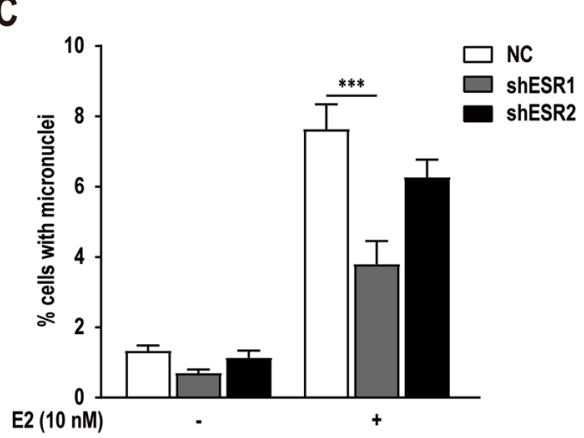

E

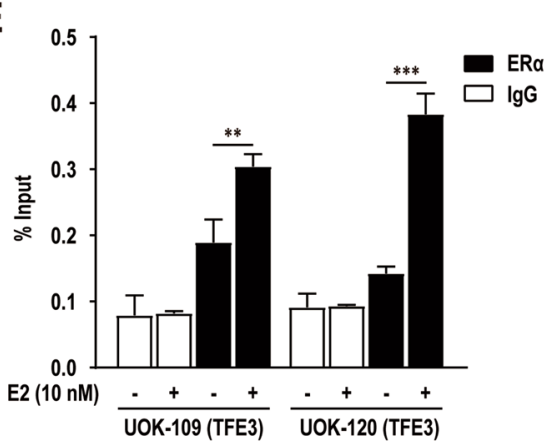

Fig. 4 (See legend on previous page.) 
sites in Xp11.2 tRCC revealed the presence of TOP2 $\beta$ in chromatin in most of the positions sampled (Fig. 3D, E). The same sites were analyzed in cells treated with $100 \mu \mathrm{M}$ etoposide for $60 \mathrm{~min}$, which resulted in a large increase in stabilized covalent TOP2 $\beta$ DNA complexes. Because CTCF has been reported to bind at anchors of chromatin loops, where requires TOP2 for the initiation of transcription [23], we measured CTCF binding in the same way (Fig. 3F, G). Sampling CTCF binding in the same positions confirmed the presence of a CTCF binding. This is further proof that the TFE3 breaks in Xp11.2 tRCC are a result of TOP2 $\beta$-mediated DNA breaks.

\section{E2 induces TFE3 breaks through ERa-dependent pathway}

To assess whether the effects of E2 are mediated via ER, we constructed shRNA-lentivirus to knockdown ESR1 or ESR2 expression in HK-2 cells (Additional file 4: Fig. S1G), and repeated the above described experiment using ESR1 and ESR2 knockdown cells. Quantification of $\gamma$-H2AX showed that the increase of DNA breaks induced by E2 was disappeared after knockdown of ESR1 (Fig. 4A, B), Similar results were also observed in subsequent $\mathrm{MN}$ assays (Fig. 4C). In order to investigate whether ER $\alpha$ were associated with TFE3 breaks in Xp11.2 tRCC, we used DNA-FISH with a "break-apart" rearrangement probe as above described. Results revealed that E2-induced TFE3 breaks were markedly attenuated in ESR1 knockdown cells (Fig. 4D). The results show that E2 induces TFE3 breaks through $\mathrm{ER} \alpha$-dependent pathway.

To verify this, ChIP-qPCR experiments were performed in HK-2 cells with the specific anti-ER $\alpha$ antibodies validated by ChIP-qPCR. The results showed that $E R \alpha$ bound to multiple sites near the translocation site of TFE3 and other partner genes (NONO and PRCC) (Fig. 4E, F). After induction with E2 (10 nM), a substantial increase in binding intensities of $E R \alpha$ was observed at these sites. These results reveal that ER $\alpha$ induce TFE3 breaks directly.

\section{TOP $2 \beta$ and ERa have a combined effect in mediating DNA breaks}

To determine the association between E2-induced DNA breaks and TOP2 $\beta$-mediated DNA breaks, HK- 2 cells were treated with a concentration gradient of etoposide
$(0,1,2,5,10,20,50$, and $100 \mu \mathrm{M})$ to determine the appropriate concentration which could induce similar numbers of breaks to $10 \mathrm{nM}$ E2 treatment (Fig. 5A, B). The results showed that etoposide treatment of $0-5 \mu \mathrm{M}$ could not induce a significant DNA breaks in HK-2 cells, and DNA breaks were significantly increased from the concentration of $10 \mu \mathrm{M}$. At the same time, the $10 \mu \mathrm{M}$ etoposide treatment group showed similar DNA breaks to that of the $10 \mathrm{nM}$ E2 group $(p>0.05)$. So, the concentration of $10 \mu \mathrm{M}$ etoposide was used in the follow-up studies to explore the combined effects of these two drugs.

The TOP2B knockdown cells and control cells were treated with $0.1 \%$ DMSO (solvent-only control), $10 \mathrm{nM}$ E2, $10 \mu \mathrm{M}$ etoposide or a combination of the two drugs, respectively. Quantification of $\gamma-\mathrm{H} 2 \mathrm{AX}$ showed that DNA breaks were significantly reduced in $T O P 2 B$ knockdown cells whether treated with E2, etoposide or a combination of the two drugs (Fig. 5C, D). Similarly, we repeated the similar experiment using ESR1 knockdown HK-2 cells. Results showed that DNA breaks were also significantly reduced in ESR1 knockdown cells whether treated with E2, etoposide or a combination of the two drugs (Fig. 5E, F). Taken together, these results indicating that TOP $2 \beta$ and ER $\alpha$ play a synergistic role in the process of DNA breaks induced by E2 or etoposide.

Based on this finding, we speculated that E2 might function by modulating the interaction between ER $\alpha$ and TOP $2 \beta$. We then performed Co-IP experiments, proteins directly bound to ER $\alpha$ were detected by western blot with anti-TOP2 $\beta$ antibodies. Unfortunately, no binding signal of TOP2 $\beta$ was observed in HK- 2 cells with or without E2 treatment (Fig. 5G). Another explanation may be that the direct binding of ER $\alpha$ to TFE 3 sequence affects the structural, and possibly the functional, properties of TOP $2 \beta$, resulting in the site-specific break in the translocation site of TFE3.

\section{Further validation in ten Xp11.2 tRCC patients}

To further verify the conclusions drawn above, we used target region sequencing to analyze the DNA sequences of the translocation site in ten Xp11.2 tRCC patients [see Additional file 1]. And primers were designed within $100 \mathrm{bp}$ before or after the translocation site, if possible. Due to the particularity of the sequence near the break site in some patients, no valuable primers

\footnotetext{
(See figure on next page.)

Fig. 5 Combined effect of TOP2 $\beta$ and ERa in mediating DNA breaks. A $\gamma H 2 A X$ focis detected in HK-2 cells under $10 \mathrm{nM}$ E2 treatment for $48 \mathrm{~h}$ or a concentration gradient of etoposide $(0,1,2,5,10,20,50,100 \mu \mathrm{M})$ for $1 \mathrm{~h}$. B Quantification of the $\gamma H 2 \mathrm{AX}$ focis in cells as in panel $\mathbf{A}$. $\mathbf{C}$ and $\mathbf{D}$ YH2AX focis detected in HK-2 cells transfected with negative control siRNA (NC), siRNA against TOP2A (siTOP2A), or siRNA against TOP2B (siTOP2B) under $0.1 \%$ DMSO (solvent-only control), $10 \mathrm{nM} \mathrm{E2,} 10 \mu \mathrm{M}$ etoposide or a combination of the two drugs and their quantification. $\mathbf{E}$ and $\mathbf{F}$ $\mathrm{YH}$ 2AX focis detected in HK-2 cells transfected with negative control shRNA (NC), shRNA against ESR1 (shESR1), or shRNA against ESR2 (shESR2) under

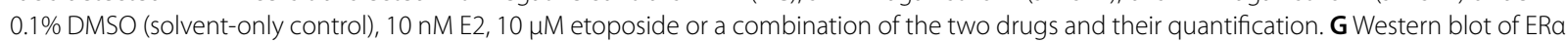
co-immunoprecipitation (Co-IP) detected with anti-Top2 $\beta$ antibodies. Error bars indicate $95 \%$ confidence intervals $\left({ }^{* * *} p<0.001\right)$
} 

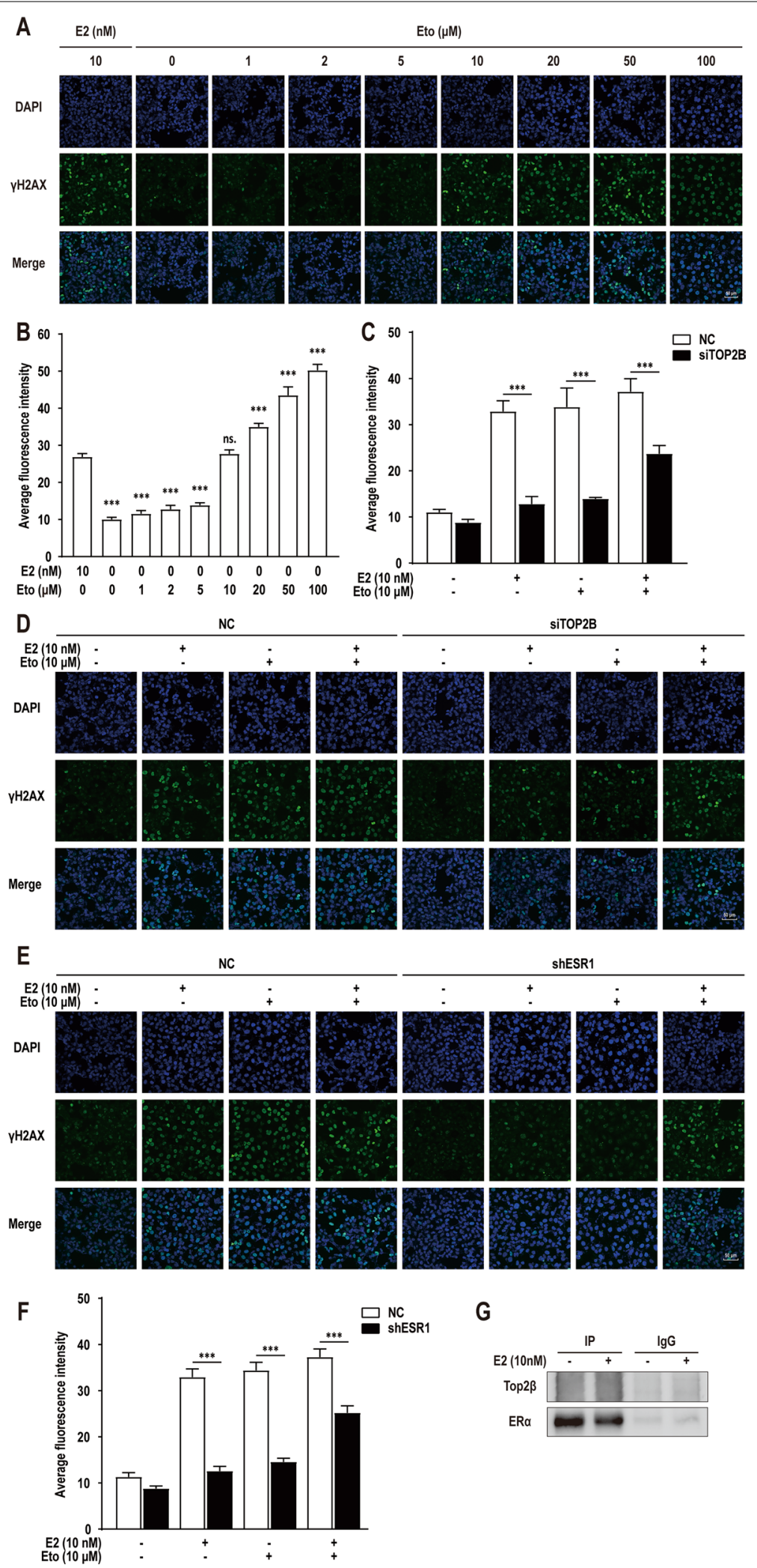

G

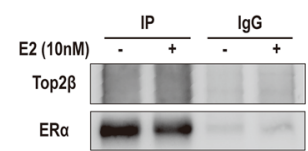

Fig. 5 (See legend on previous page.) 
can be designed for PCR operation. These specific sites were excluded from our study. In subsequent research, we consider using a more systematic high-throughput method ChIP-sequence to focus on these specific individuals. We then used ChIP-qPCR to determine the distribution of TOP2 $\beta$ and ER $\alpha$ over the translocation sites in ten Xp11.2 tRCC patients, using HK-2 cells with or without etoposide or E2 treatment respectively. The results showed that TOP $2 \beta$ and ER $\alpha$ extensively bound to multiple sites near the translocation site of TFE3 and other partner genes (NONO, PRCC, SFPQ, ASPSCR 1 and MED15) (Fig. 6A-D). This is further proof that the TFE3 breaks in Xp11.2 tRCC are a result of ER $\alpha$ and TOP2 $\beta$ mediated DNA breaks.

E2 increases the risk of TFE3 breaks through NRF1 pathway To investigate whether E2 can be regulated TFE3 expression, we tested renal TFE3 mRNA level and serum E2 concentration in BalbC mice aged 4-10 weeks. Results showed that TFE3 expression was significantly associated with E2 concentration (Fig. 7A). We further observed that dose-dependent significant increases in TFE3 and ESR1 with increasing E2 concentration in HK-2 cells (Fig. 7B, C). We considered whether activation of TFE3 expression by $E R \alpha$-dependent pathway could increase the risk of TFE3 breaks. However, there was no ER $\alpha$-binding site in the promoter region of TFE3, predicted by using the online website JASPAR (http://jaspar.genereg.net/). To identify putative transcription factors that can bind to the promoter region of TFE3, we systematically searched databases of known human transcription factors [see Additional file 2]. Results are sorted by best relative score. Apart from a broad-spectrum binding protein to zinc finger domain, ZNF263, the highest score was given to NRF1. Since the ability of E2 to regulate NRF1 expression has been widely confirmed by previous researches [24], we then examined whether NRF1 was involved in TFE3 expression induced by E2. We found that TFE3 expression was drastically reduced following NRF1 knockdown, and the dose-dependent increases was also disappeared with increasing E2 concentration (Fig. 7D, E and Additional file 4: Fig. S1H). Together, the results show that E2 upregulates TFE3 expression by enhancing its transcriptional activity through NRF1 pathway and consequently increases the risk of TFE3 breaks.

\section{Discussion}

Since Xp11.2 tRCC has been formally described as a distinct clinicopathologic entity in 2001, there has been a lot of research attention given to the function of TFE3 fusion proteins [25-27]. However, few studies have investigated the pathogenesis of Xp11.2 tRCC. Our study proposed that physiological concentrations of E2 could induce TFE3 breaks in Xp11.2 tRCC, which explained the high morbidity in women. In this study, we confirmed that TFE3 breaks were mediated by TOP2 $\beta$, which process could be amplified through ER $\alpha$-dependent pathway induced by E2. Although TOP2 $\beta$ and ER $\alpha$ could both bind to TFE3 translocation sites directly to mediate DNA breaks, no direct interaction was observed, indicating that their collaborative may be implemented in other ways. Besides, TFE3 was found to be upregulated through NRF1 with increasing E2 concentration, which could increase the risk of TFE3 breaks.

Different from etoposide with rapid onset, E2 require an extended period ( $48 \mathrm{~h}$ ) of treatment to induce TFE3 breaks. On the one hand, this may because the indirectly affected of ER $\alpha$-mediated DNA breaks is less prominently than acting directly on TOP $2 \beta$. On the other hand, E2 induced increase in transcriptional activity of TFE3 requires the expression of $N R F 1$, resulting in a delayed TFE3 breaks. This may explain the reason why the peak age of onset is 20-29 years instead of the early pubertal stages suffering initial exposure with high concentrations of E2 [5].

Several studies reported about the function of sex hormone in TOP2 $\beta$-mediated DNA breaks. Michael et al. [28] find that TOP2 $\beta$ mediates DNA breaks through directly binding to androgen receptor at the position of androgen receptor downstream target gene promoters. We pre-retrieved and analyzed the corresponding ChIPseq data through the Cistrome DB database (http://cistr ome.org/). The results showed that TOP2 $\beta$ and CTCF were both found to bind to the TFE3 gene and partner genes we were concerned about (PRCC, SFPQ, ASPSCR1, NONO, MED-15) [see Additional file 3]. Since TOP2 $\beta$ has been proved to mediate DNA breaks [29], we used

\footnotetext{
(See figure on next page.)

Fig. 6 E2-induced ERa and TOP2 $\beta$-dependent TFE3 breaks in translocation sites of ten Xp11.2 tRCC patients. A Statistics of TOP2 $\beta$ ChIP-qPCR results performed using primers designed for partner genes (NONO, PRCC, SFPQ, ASPSCR1 and MED15) in ten Xp11.2 tRCC patients in HK-2 cells under $0.1 \%$ DMSO (solvent-only control) or $100 \mu \mathrm{M}$ etoposide treatment for $1 \mathrm{~h}$. B Statistics of TOP2 $\beta$ ChIP-qPCR results performed using primers designed for TFE3 in ten Xp11.2 tRCC patients in HK-2 cells under 0.1\% DMSO (solvent-only control) or $100 \mu \mathrm{M}$ etoposide treatment for $1 \mathrm{~h}$. C Statistics of ERa ChIP-qPCR results performed using the same primers as in panel $\mathbf{A}$ in HK-2 cells under $0.1 \%$ DMSO (solvent-only control) or $10 \mathrm{nM}$ E2 treatment for 48 h. D Statistics of ERa ChIP-qPCR results performed using the same primers as in panel $\mathbf{B}$ in HK-2 cells under 0.1\% DMSO (solvent-only control) or $10 \mathrm{nM}$ E2 treatment for $48 \mathrm{~h}$. ChIP-qPCR was normalized to Input DNA, experiments were repeated three times and data shown are means \pm SD. Error bars indicate $95 \%$ confidence intervals $\left({ }^{* * *} p<0.001\right)$
} 


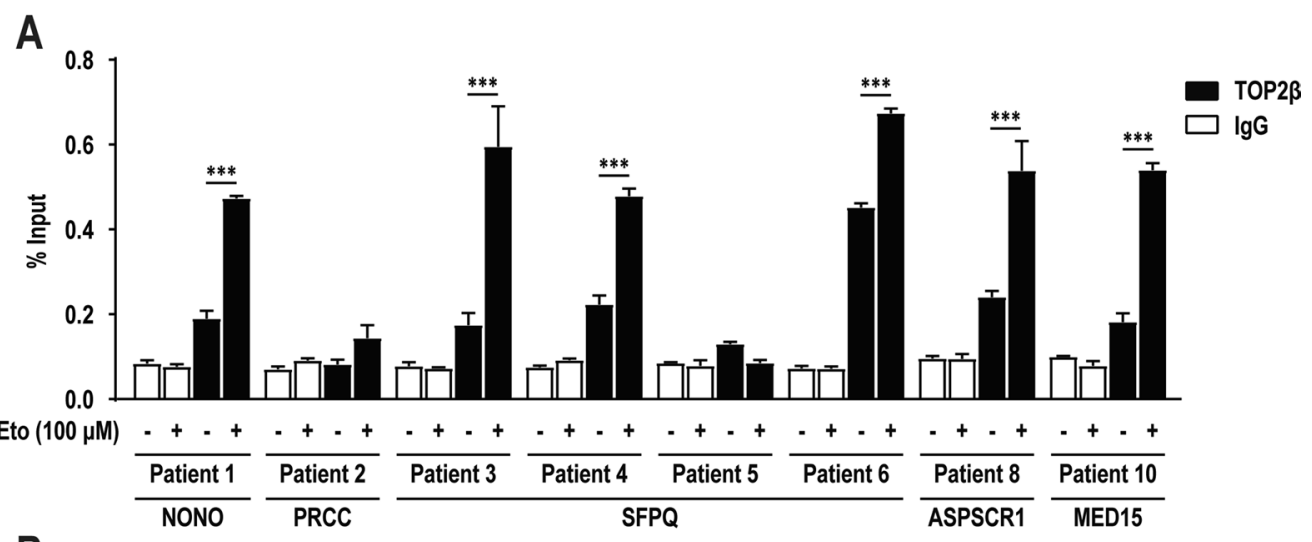

B

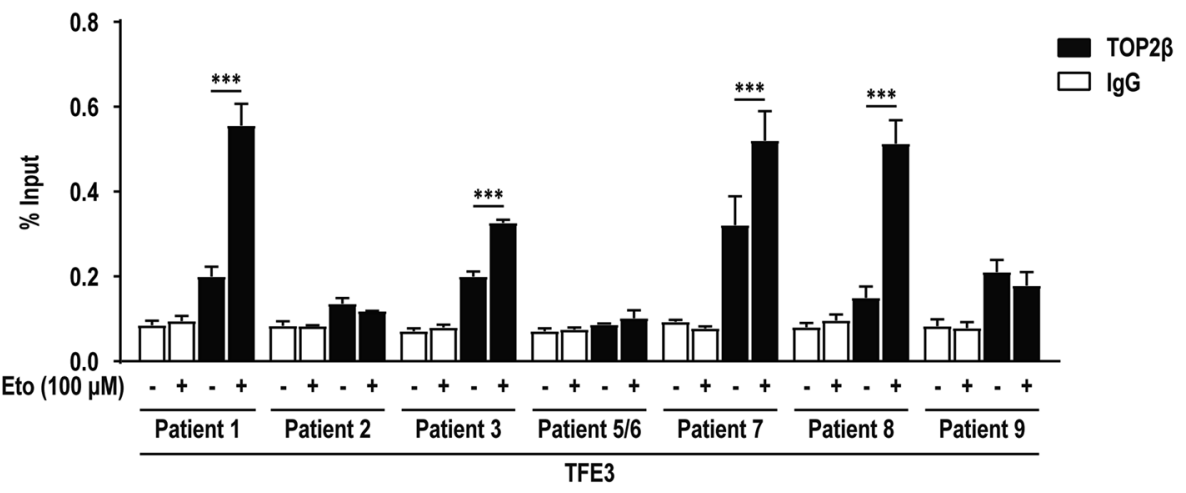

C

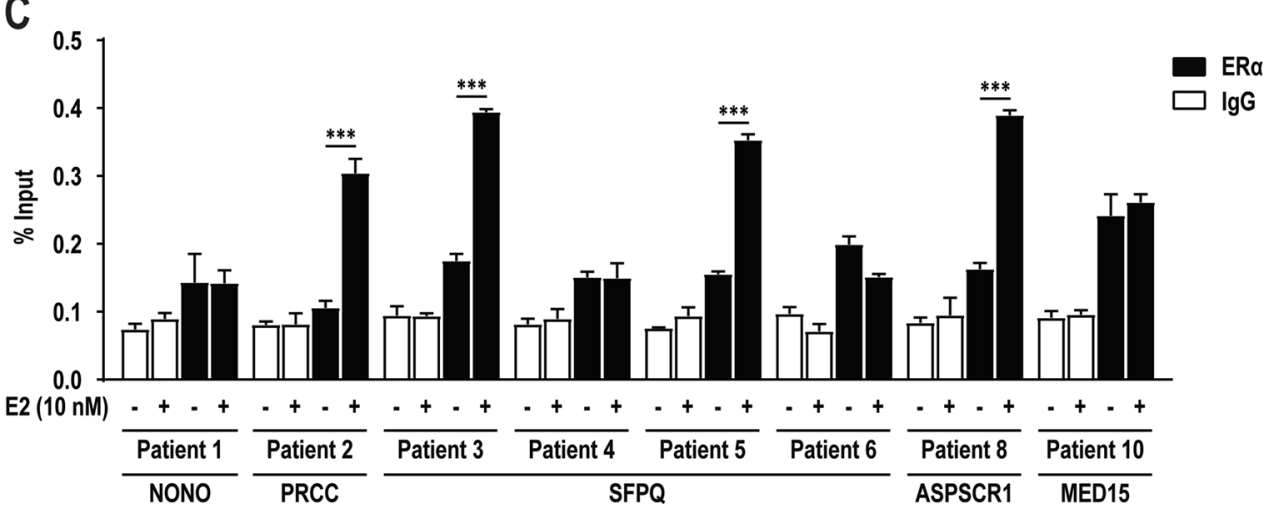

D

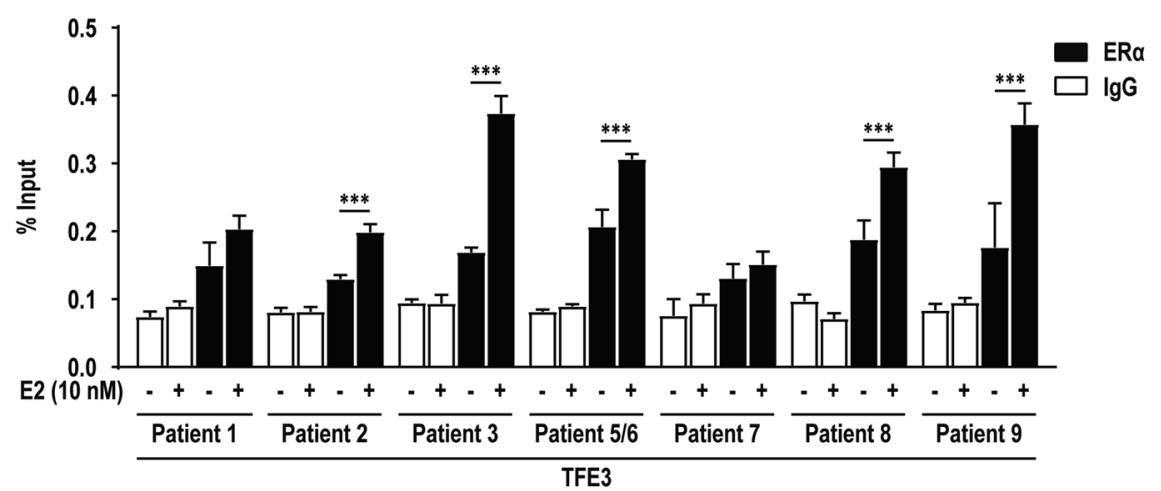

Fig. 6 (See legend on previous page.) 
A

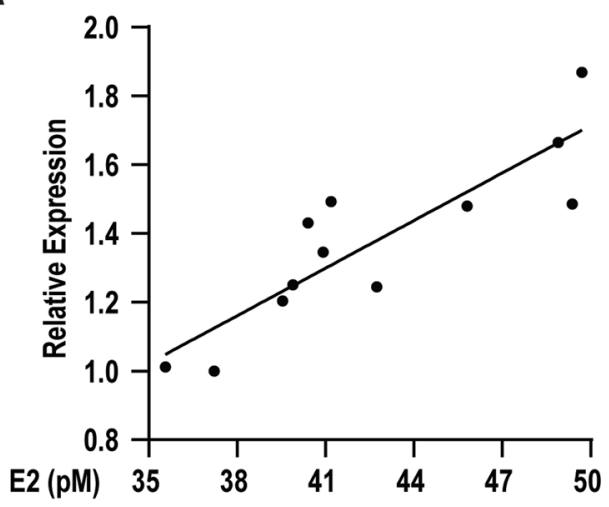

C

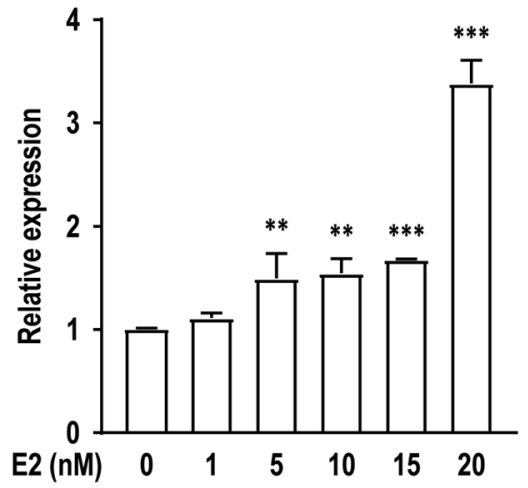

$\mathrm{E}$

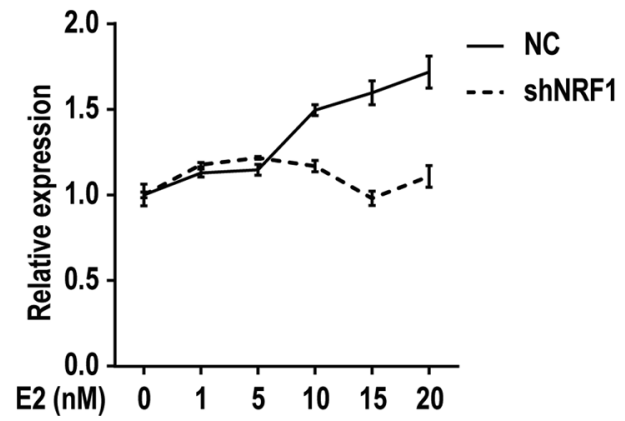

B

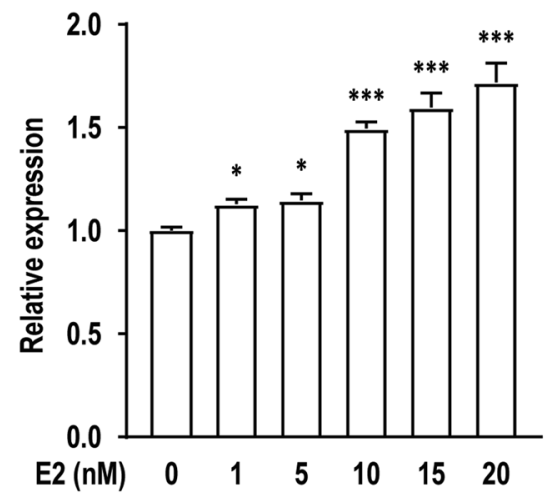

D

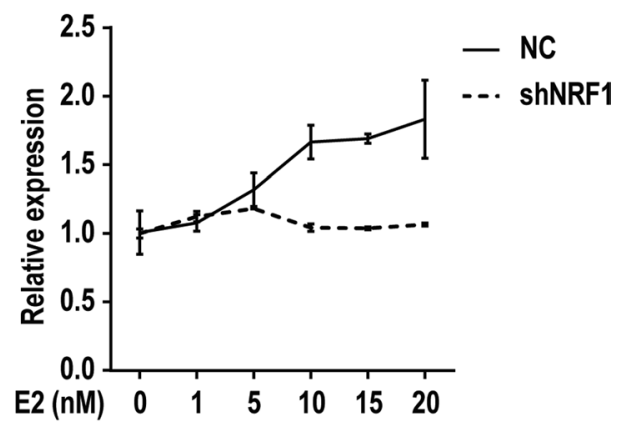

Fig. 7 E2-induced NRF1-dependent TFE3 expressions. A Correlation analysis of TFE3 mRNA level and serum E2 concentration in BalbC mice aged 4-10 weeks. B Statistics of TFE3 qPCR results in HK-2 cells under 0.1\% DMSO (solvent-only control), $1 \mathrm{nM}, 5 \mathrm{nM}, 10 \mathrm{nM}, 15 \mathrm{nM}$ or $20 \mathrm{nM}$ E2 treatment for 48 h. C Statistics of ESR1 qPCR results in E2-treated cells as in panel B. D Statistics of TFE3 qPCR results in HK-2 cells transfected with negative control shRNA (NC) or shRNA against NRF1 (shNRF1) under the same treatment as in panel B. E Statistics of NRF1 qPCR results in E2-treated cells as in panel $\mathbf{D}$. Error bars indicate $95 \%$ confidence intervals $\left({ }^{*} p<0.05 ;{ }^{* *} p<0.01\right.$; ${ }^{* *} p<0.001$ )

TOP2 $\beta$ ChIP to demonstrate the binding of TOP2 $\beta$ at the translocation sites to prove that the TFE3 gene could break at the translocation sites through TOP2 $\beta$-mediated DNA breaks. And we used TFE3 break-apart FISH to detect TFE3 breaks. The further ER $\alpha$ ChIP was also used to explore the potential effects of ER $\alpha$ on TOP2 $\beta$ at the translocation site. However, our study failed to find the direct bindings of ER $\alpha$ and TOP2 $\beta$, we proposed that
ER $\alpha$ and TOP2 $\beta$ could be co-recruited to translocation sites in the intron regions rather than only in the promoter regions. Based on the study that TOP2 cleaves DNA double strands to results in TOP2 cleavage complex (TOP2cc) through a transesterification reaction [30], we put forward hypothesis that, in a narrow spatial chromatin region, the binding of ER $\alpha$ with DNA sequence near the breaking site may have spatial-dependent harms on 
the biological functions of TOP2cc, making TOP2cc fall off from DNA strands, and finally resulting in DNA breaks. Thus, further research should be done to prove this hypothesis. And we found evidence for enrichment of CTCF at TFE3 translocation sites, implying that TFE3 translocation sites may located in anchors of chromatin loops [29]. This also explains why TFE3 translocation sites are more located in the intron 3-4 and intron 5-6, based on the DNA fragility caused by spatial chromosome folding [31, 32].

Studies confirm that TOP2-mediated DNA breaks acts primarily through transcription-dependent processes [30,33], suggesting a higher risk of DNA breaks in highly transcribed genes. And the effect of estrogen on the occurrence of tumors has been widely concerned. Previous animal experiments have confirmed that estrogen can induce the occurrence of hamster kidney tumors [34]. Estrogen is an important reproductive endocrine hormone, which regulates the expression of thousands of genes by combining with ER. ER $\alpha$ expression predominant in uterus, pituitary, kidney, and adrenal gland and ER $\beta$ expression predominant in ovarian granulosa cells, prostate, bladder, and lung [35]. Among all genes regulated by estrogen, the number of genes expressed by the kidney ranks third, and even more than that of ovarian granulosa cells [36]. Therefore, we considered that E2 could upregulate TFE3 expression by enhancing its transcriptional activity through NRF1 pathway, and consequently increase the risk of TFE3 breaks. And finally, we found that E2 regulated TFE3 transcription via NRF-1. As the publication work of the detailed research on the regulation of TFE3 transcription by NRF1 is in progress, only a brief verification was provided in this study. On the other hand, when reviewing the transcript levels of fusion partners in Xp11.2 tRCC, we found that some of them were housekeeping genes with high transcriptional activity [37], such as NONO and CLTC. This caused that these fusion partners are more accessible to face DNA breaks and chromosome translocations, which reflected that the seemingly random chromosome translocations might have an inevitable reason.

Besides, based on the specificity of the TFE3 gene, studies have confirmed that TFE3 can be activated during DNA damage, and play an important role by directly regulating p53, causing cell cycle arrest or apoptosis [38]. Which means the changes in TFE3 protein function by the translocation at Xp11.2 can further aggravate the consequences of DNA damage, and thus played an important role in this process of tumorigenesis.

In a sense, this study offers a method for predicting translocation sites in Xp11.2 tRCC. Our data indicated that ER $\alpha$ and TOP2 $\beta$ were co-recruited to translocation sites not only in TFE3 gene, but also in fusion partner genes. Conversely, we can explore new fusion partners or translocation sequences by analyzing the intersection between ER $\alpha$-bound sequence and TOP2 $\beta$-bound sequence. However, the generation of tRCC involves not only the occurrence of DNA breaks, but also obstacles to the double-strand repair mechanism. Considering that this was a multi-factor participation process, other factors such as gene mutation, sudden changes in hormone levels were also play an important role. The pathogenesis of tRCC cannot not be predicted by ER $\alpha$ and TOP $2 \beta$ alone. Through further studies of potential translocation sequence in fusion partners, the rules governing fusion partner choice in Xp11.2 tRCC may be delineated.

\section{Conclusions}

This study indicates that E2 amplifies TOP2 $\beta$-mediated TFE3 breaks by ER $\alpha$-dependent pathway, and E2 upregulates TFE3 by NRF1 to increase the risk of TFE3 breaks. Which suggests that E2 is an important pathogenic factor for Xp11.2 tRCC pathogenesis.

\section{Abbreviations}

tRCC: Translocation renal cell carcinoma; TFE3: Transcription factor E3; TOP2: Topoisomerase II; E2: 17ß-Estradiol; ER: Estrogen receptor; BPE: Bovine pituitary extract; EGF: Epidermal growth factor; FISH: Fluorescence in-situ hybridization; ChIP: Chromatin immunoprecipitation; Co-IP: Co-immunoprecipitation; Y-H2AX: Phosphorylated H2AX; MN: Micronuclei; NRF1: Nuclear respiratory factor 1;TOP2cc: TOP2 cleavage complex

\section{Supplementary Information}

The online version contains supplementary material available at https://doi. org/10.1186/s12964-021-00790-3.

Additional file 1. Sequences of probes, primers, siRNAs and shRNAs used, and translocation sites metioned in this study.

Additional file 2. Results of putative transcription factors that can bind to the promoter region of TFE3.

Additional file 3. ChIP-seq data analysis from Cistrome DB database.

Additional file 4. Figure S1. Supplementary figures. (A) Detection of Cell Counting Kit-8 (CCK8) cell viability in HK-2 cells under $0.1 \%$ DMSO (solvent-only control), $50 \mu \mathrm{M}, 75 \mu \mathrm{M}, 100 \mu \mathrm{M}, 125 \mu \mathrm{M}$ or $150 \mu \mathrm{M}$ etoposide treatment for $1 \mathrm{~h}$. (B) Western blot detection of TOP2 $a$ and TOP2 $\beta$ in HK2 cells (three biological replicates). (C) Knockdown efficiency of siTOP2A and siTOP2B detected by QPCR. (D) Representative image of micronuclei (pointed by the yellow arrow). (E) Western blot of total protein of HK-2 cells detected with anti-ERa antibodies (Three biological replicates). (F) Immunofluorescence assay of ERa in HK-2 cells. (G) Knockdown efficiency of shESR1 and shESR2 detected by qPCR. (H) Knockdown efficiency of shNRF1 detected by qPCR. Error bars indicate $95 \%$ confidence intervals (** $\left.p<0.01,{ }^{* * *} p<0.001\right)$

\section{Acknowledgements}

Not applicable.

\section{Authors' contributions}

Conception and design: QS. Acquisition of data: QS. Analysis and interpretation of data: QS. Drafting of the manuscript: QS. Critical revision of the manuscript for important intellectual content: QS, NL, DL. Statistical analysis: QS. 
Obtaining funding: DL, WG. Administrative, technical, or material support: NL, $L Y, Y C, Y L, H G, X H, D L, W G$. All authors read and approved the final manuscript.

\section{Funding}

This research was supported by the State Key Laboratory of Analytical Chemistry for Life Science (5431ZZXM2004), and Beijing Ronghe Medical Development Foundation. The funders had no role in study design, data collection and analysis, decision to publish, or preparation of the manuscript.

\section{Availability of data and materials}

Supporting data were available to all researchers.

\section{Declarations}

\section{Ethical approval and consent to participate.}

This study was approved by the Ethics Committee of Drum Tower Hospital, The Affiliated Hospital of Nanjing University Medical School.

\section{Consent for publication}

This study was completed and consented to be published.

\section{Competing interests}

The authors declare that they have no competing interests.

\section{Author details \\ ${ }^{1}$ Department of Urology, Affiliated Drum Tower Hospital, Medical School of Nanjing University, Nanjing, Jiangsu, China. ${ }^{2}$ Department of Urology, Nanjing First Hospital, Nanjing Medical University, Nanjing, Jiangsu, China. ${ }^{3}$ Immunology and Reproduction Biology Laboratory and State Key Laboratory of Analytical Chemistry for Life Science, Medical School, Nanjing University, Nanjing, Jiangsu, China. ${ }^{4}$ Jiangsu Key Laboratory of Molecular Medicine, Nanjing University, Nanjing, Jiangsu, China.}

\section{Received: 25 May 2021 Accepted: 1 October 2021}

Published online: 16 November 2021

\section{References}

1. de Jong B, Oosterhuis JW, Idenburg VJ, Castedo SM, Dam A, Mensink HJ. Cytogenetics of 12 cases of renal adenocarcinoma. Cancer Genet Cytogenet. 1988;30(1):53-61.

2. Argani P. MiT family translocation renal cell carcinoma. Semin Diagn Pathol. 2015;32(2):103-13.

3. Geller JI, Ehrlich PF, Cost NG, Khanna G, Mullen EA, Gratias EJ, Naranjo A, Dome JS, Perlman EJ. Characterization of adolescent and pediatric renal cell carcinoma: a report from the Children's Oncology Group study AREN03B2. Cancer. 2015:121(14):2457-64.

4. Kuroda N, Mikami S, Pan CC, Cohen RJ, Hes O, Michal M, Nagashima Y, Tanaka Y, Inoue K, Shuin T, Lee GH. Review of renal carcinoma associated with Xp11.2 translocations/TFE3 gene fusions with focus on pathobiological aspect. Histol Histopathol. 2012;27(2):133-40.

5. Caliò A, Segala D, Munari E, Brunelli M, Martignoni G. MiT family translocation renal cell carcinoma: from the early descriptions to the current knowledge. Cancers. 2019;11(8):1110.

6. Argani P, Olgac S, Tickoo SK, Goldfischer M, Moch H, Chan DY, Eble JN, Bonsib SM, Jimeno M, Lloreta J, Billis A, Hicks J, De Marzo AM, Reuter VE, Ladanyi M. Xp1 1 translocation renal cell carcinoma in adults: expanded clinical, pathologic, and genetic spectrum. Am J Surg Pathol. 2007;31(8):1149-60.

7. Mir MC, Trilla E, de Torres IM, Panizo A, Zlotta AR, Van Rhijn B, Morote J. Altered transcription factor E3 expression in unclassified adult renal cell carcinoma indicates adverse pathological features and poor outcome. BJU Int. 2011:108(2 Pt 2):E71-6.

8. Ellis $\mathrm{CL}$, Eble JN, Subhawong AP, Martignoni G, Zhong M, Ladanyi M, Epstein JI, Netto GJ, Argani P. Clinical heterogeneity of Xp11 translocation renal cell carcinoma: impact of fusion subtype, age, and stage. Modern Pathol. 2014;27(6):875-86

9. He J, Chen X, Gan W, Zhu B, Fan X, Guo H, Jia R. Renal cell carcinoma associated with Xp11.2 translocation/TFE3 gene fusions: clinical experience and literature review. Future Oncol (London, England). 2015;11(24):3243-52

10. Cheng X, Gan W, Zhang G, Li X, Guo H. Clinical characteristics of XP11.2 translocation/TFE3 gene fusion renal cell carcinoma: a systematic review and meta-analysis of observational studies. BMC Urol. 2016;16(1):40.

11. Zhuang W, Liu N, Guo H, Zhang C, Gan W. Gender difference analysis of Xp11.2 translocation renal cell carcinomas's attack rate: a meta-analysis and systematic review. BMC Urol. 2020;20(1):130.

12. Siegel RL, Miller KD, Jemal A. Cancer statistics, 2020. CA: Cancer J Clin. 2020;70(1):7-30.

13. Argani P, Laé M, Ballard ET, Amin M, Manivel C, Hutchinson B, Reuter VE, Ladanyi M. Translocation carcinomas of the kidney after chemotherapy in childhood. J Clin Oncol. 2006;24(10):1529-34.

14. Al-Mashaikhi N, Yang J, Terry J, Barr R. Renal cell carcinoma with Xp 11.2 translocation as a second tumor in a long-term survivor of advanced neuroblastoma. Pediatr Hematol Oncol. 2015;32(3):215-22.

15. Rais-Bahrami S, Drabick JJ, De Marzo AM, Hicks J, Ho C, Caroe AE, Argani P. Xp11 translocation renal cell carcinoma: delayed but massive and lethal metastases of a chemotherapy-associated secondary malignancy. Urology. 2007:70(1):178.e3-6.

16. Nitiss JL. Targeting DNA topoisomerase II in cancer chemotherapy. Nat Rev Cancer. 2009;9(5):338-50

17. Mirault ME, Boucher P, Tremblay A. Nucleotide-resolution mapping of topoisomerase-mediated and apoptotic DNA strand scissions at or near an MLL translocation hotspot. Am J Hum Genet. 2006;79(5):779-91.

18. Cowell IG, Sondka Z, Smith K, Lee KC, Manville CM, Sidorczuk-Lesthuruge M, Rance HA, Padget K, Jackson GH, Adachi N, Austin CA. Model for MLL translocations in therapy-related leukemia involving topoisomerase $\| \beta$ mediated DNA strand breaks and gene proximity. Proc Natl Acad Sci USA. 2012;109(23):8989-94.

19. Ju BG, Lunyak W, Perissi V, Garcia-Bassets I, Rose DW, Glass CK, et al. A topoisomerase llbeta-mediated dsDNA break required for regulated transcription. Science (New York, NY). 2006;312(5781):1798-802.

20. Sasanuma H, Tsuda M, Morimoto S, Saha LK, Rahman MM, Kiyooka Y, Fujiike H, Cherniack AD, Itou J, Callen Moreu E, Toi M, Nakada S, Tanaka H, Tsutsui K, Yamada S, Nussenzweig A, Takeda S. BRCA1 ensures genome integrity by eliminating estrogen-induced pathological topoisomerase II-DNA complexes. Proc Natl Acad Sci USA. 2018;115(45):E10642-51.

21. Anglard P, Trahan E, Liu S, Latif F, Merino MJ, Lerman MI, Zbar B, Linehan WM. Molecular and cellular characterization of human renal cell carcinoma cell lines. Cancer Res. 1992;52(2):348-56.

22. Fenech $\mathrm{M}$. The in vitro micronucleus technique. Mutat Res. 2000;455(1-2):81-95.

23. Uusküla-Reimand L, Hou H, Samavarchi-Tehrani P, Rudan MV, Liang M, Medina-Rivera A, Mohammed H, Schmidt D, Schwalie P, Young EJ, Reimand J, Hadjur S, Gingras AC, Wilson MD. Topoisomerase II beta interacts with cohesin and CTCF at topological domain borders. Genome Biol. 2016;17(1):182

24. Das JK, Felty Q, Poppiti R, Jackson RM, Roy D. Nuclear respiratory factor 1 acting as an oncoprotein drives estrogen-induced breast carcinogenesis. Cells. 2018;7(12):234.

25. Argani P, Antonescu CR, Illei PB, Lui MY, Timmons CF, Newbury R, Reuter VE, Garvin AJ, Perez-Atayde AR, Fletcher JA, Beckwith JB, Bridge JA, Ladanyi M. Primary renal neoplasms with the ASPL-TFE3 gene fusion of alveolar soft part sarcoma: a distinctive tumor entity previously included among renal cell carcinomas of children and adolescents. Am J Pathol. 2001;159(1):179-92.

26. Yin X, Wang B, Gan W, Zhuang W, Xiang Z, Han X, Li D. TFE3 fusions escape from controlling of mTOR signaling pathway and accumulate in the nucleus promoting genes expression in Xp11.2 translocation renal cell carcinomas. J Exp Clin Cancer Res. 2019;38(1):119.

27. Wang B, Yin X, Gan W, Pan F, Li S, Xiang Z, Han X, Li D. PRCC-TFE3 fusionmediated PRKN/parkin-dependent mitophagy promotes cell survival and proliferation in PRCC-TFE3 translocation renal cell carcinoma. Autophagy. 2020;17:2475-93.

28. Haffner MC, Aryee MJ, Toubaji A, Esopi DM, Albadine R, Gurel B, Isaacs WB, Bova GS, Liu W, Xu J, Meeker AK, Netto G, De Marzo AM, Nelson WG, Yegnasubramanian S. Androgen-induced TOP2B-mediated doublestrand breaks and prostate cancer gene rearrangements. Nat Genet. 2010:42(8):668-75. 
29. Gothe HJ, Bouwman BAM, Gusmao EG, Piccinno R, Petrosino G, Sayols S, Drechsel O, Minneker V, Josipovic N, Mizi A, Nielsen CF, Wagner EM, Takeda S, Sasanuma H, Hudson DF, Kindler T, Baranello L, Papantonis A, Crosetto N, Roukos V. Spatial chromosome folding and active transcription drive DNA fragility and formation of oncogenic MLL translocations. Mol Cell. 2019;75(2):267-83.e12.

30. Ashour ME, Atteya R, El-Khamisy SF. Topoisomerase-mediated chromosomal break repair: an emerging player in many games. Nat Rev Cancer. 2015:15(3):137-51.

31. Tretiakova MS, Wang W, Wu Y, Tykodi SS, True L, Liu YJ. Gene fusion analysis in renal cell carcinoma by FusionPlex RNA-sequencing and correlations of molecular findings with clinicopathological features. Genes Chromosomes Cancer. 2019;59:40-9.

32. Macher-Goeppinger S, Roth W, Wagener N, Hohenfellner M, Penzel R, Haferkamp A, Schirmacher P, Aulmann S. Molecular heterogeneity of TFE3 activation in renal cell carcinomas. Modern Pathol. 2012;25(2):308-15.

33. Canela A, Maman Y, Huang SYN, Wutz G, Nussenzweig A. Topoisomerase II-Induced chromosome breakage and translocation is determined by chromosome architecture and transcriptional activity. Mol Cell. 2019:75(2):252-66.e8.

34. Liehr JG, Roy D. Free radical generation by redox cycling of estrogens. Free Radical Biol Med. 1990;8(4):415-23.
35. Kuiper GG, Carlsson B, Grandien K, Enmark E, Häggblad J, Nilsson S, et al. Comparison of the ligand binding specificity and transcript tissue distribution of estrogen receptors alpha and beta. Endocrinology. 1997;138(3):863-70.

36. Jelinsky SA, Harris HA, Brown EL, Flanagan K, Zhang X, Tunkey C, et al. Global transcription profiling of estrogen activity: estrogen receptor alpha regulates gene expression in the kidney. Endocrinology. 2003;144(2):701-10

37. Hsiao LL, Dangond F, Yoshida T, Hong R, Jensen RV, Misra J, Dillon W, Lee KF, Clark KE, Haverty P, Weng Z, Mutter GL, Frosch MP, MacDonald ME, Milford EL, Crum CP, Bueno R, Pratt RE, Mahadevappa M, Warrington JA, Stephanopoulos G, Stephanopoulos G, Gullans SR. A compendium of gene expression in normal human tissues. Physiol Genomics. 2001;7(2):97-104

38. Brady OA, Jeong E, Martina JA, Pirooznia M, Tunc I, Puertollano R. The transcription factors TFE3 and TFEB amplify p53 dependent transcriptional programs in response to DNA damage. Elife. 2018;7:e40856.

\section{Publisher's Note}

Springer Nature remains neutral with regard to jurisdictional claims in published maps and institutional affiliations.
Ready to submit your research? Choose BMC and benefit from:

- fast, convenient online submission

- thorough peer review by experienced researchers in your field

- rapid publication on acceptance

- support for research data, including large and complex data types

- gold Open Access which fosters wider collaboration and increased citations

- maximum visibility for your research: over $100 \mathrm{M}$ website views per year

At BMC, research is always in progress.

Learn more biomedcentral.com/submissions 